\title{
Morphological, molecular, and pathogenicity characteristics of the native isolates of Metarhizium anisopliae against the tomato leafminer, Tuta absoluta (Meyrick 1917) (Lepidoptera: Gelechiidae) in Ethiopia
}

Birhan Aynalem Ayele ${ }^{1 *} \mathbb{D}$, Diriba Muleta', Juan Venegas ${ }^{2}$ and Fassil Assefa ${ }^{3}$

\begin{abstract}
The South American tomato leafminer, Tuta absoluta (Meyrick 1917) (Lepidoptera: Gelechiidae), is a newly introduced and a major threat of tomato production in Ethiopia. Laboratory bioassay was conducted to evaluate locally isolated Metarhizium anisopliae (Metsch.) (Sorokin), against larvae of T. absoluta. Twenty-five Metarhizium isolates were isolated from different soil types, using the great wax moth, Galleria mellonella L. baiting method. From these, 13 isolates were prescreened by biological efficiency index model and tested against 2nd and 3rd larval instars of T. absoluta at the concentration of $10^{7}$ spores $\mathrm{ml}^{-1}$. Sterile water plus Tween $80(0.1 \% \mathrm{~V} / \mathrm{V})$ was used as a control. Greenhouse reared larvae of T. absoluta were used as experimental organisms. All tested Metarhizium formulations were pathogenic to T. absoluta in all conducted bioassays. Three isolates, AAUM78, AAUM39, and AAUM76, were the most effective and scored 88, 90, and 95\% and 90, 93.3, and 95.7\% mortality against 2nd and 3rd larval instars of $T$. absoluta, respectively. The lowest ( 48.5 and 50\%) mortality rate was recorded by isolate AAUM30 against 2 nd and $3 r d$ larval instars, respectively, in 7 days post inoculation. However, all isolates showed significant statistical differences with $F(24,50)=6.825, p<0.001$ and $F(23,15)=3.97, p<0.001$ of mortality to 2nd and 3rd larval instars, respectively. Molecular analysis categorized these selected isolates under species of $M$. anisopliae and grouped into 2 different groups. AAUM78 and AAUM39 were recorded $L T_{50}$ values of 3.93 and 3.5 days at the lowest $\left(10^{4}\right.$ spore $\left.\mathrm{ml}^{-1}\right)$ concentration and $L C_{50}$ values of $1.2 \times 10^{3}$ and $2.9 \times 10^{3}$ spore $\mathrm{ml}^{-1}$, respectively. Although AAUM78 and AAUM39 were virulent to the target pest, further field evaluation is required to determine their potential efficacy for T. absoluta control.
\end{abstract}

Keywords: Tuta absoluta, Entomopathogenic fungi, M. anisopliae, Mycoinsecticide, Biocontrol

\footnotetext{
* Correspondence: berha.bat@gmail.com

${ }^{1}$ Institute of Biotechnology, Addis Ababa University, Addis Ababa, Ethiopia

Full list of author information is available at the end of the article
}

\section{Springer Open}

( ) The Author(s). 2020 Open Access This article is licensed under a Creative Commons Attribution 4.0 International License, which permits use, sharing, adaptation, distribution and reproduction in any medium or format, as long as you give appropriate credit to the original author(s) and the source, provide a link to the Creative Commons licence, and indicate if changes were made. The images or other third party material in this article are included in the article's Creative Commons licence, unless indicated otherwise in a credit line to the material. If material is not included in the article's Creative Commons licence and your intended use is not permitted by statutory regulation or exceeds the permitted use, you will need to obtain permission directly from the copyright holder. To view a copy of this licence, visit http://creativecommons.org/licenses/by/4.0/. 


\section{Background}

Fungal entomopathogens (EPFs) are cosmopolitan organisms in different habitats and environmentally suited alternatives for pest control (Niu et al. 2019). Several mycoinsecticides have been formulated from different species of EPFs worldwide (Fang et al. 2014). Among these, the genus Metarhizium comprises generalist and specialist species based on their host range (Moonjely and Bidochka 2019). Metarhizium anisopliae, M. brunneum, and $M$. robertsii are generalists and infect insect pests from several orders, whereas $M$. acridum is a specialist and a specific to order Orthoptera (Wang et al. 2016). However, both groups have similar infection mechanism described as spore adhesion, spore germination, cuticle penetration, and mycelial dissemination through body hemolymph, outgrow over the cadavers of dead insects and produce disseminative green muscardine (conidial masses), which is important for horizontal dispersion to other insects (San Aw and Hue 2017).

Further molecular phylogenetic analysis categorized 4 of the most important species, $M$. pingshaense, $M$. anisopliae, $M$. robertsii, and $M$. brunneum, into monophyletic groups, which were descended from $M$. anisopliae (Mayerhofer et al. 2019). These Metarhizium species were abundant in versatile habitats particularly, forest soil (Nishi et al. 2018), organic soil (Clifton et al. 2015), farm soil (Stranne 2014), rhizospheric soil (Nishi and Sato 2019), and insect cadavers (Meng et al. 2017). Usually, a large occurrence of Metarhizium was reported from farm and forest soil (Nishi et al. 2018), which is an important attribute to have candidates easily adaptable to farmland ecosystem.

Formulated Metarhizium mycoinsecticides showed sounding efficacy against several important arthropod pests (Ndereyimana et al. 2019). Especially, the effectiveness of Metarhizium species against invasive (Onsongo et al. 2019), insecticidal resistance (Lovett et al. 2019), and secondary pests (FAO 2017) emerged through time were noteworthy. These characteristics were capturing the attention of many stakeholders to upgrade biopesticide development. However, the virulence level of EPFs depends on the environmental conditions that they were originated and the efficiency was variable in between strains based on the biotic and abiotic situations that they were obtained. Thus, augmentation of locally isolated strains through pathogenicity screening has paramount importance to increase the chance of obtaining effective microbial biopesticides.

Tuta absoluta (Meyrick 1917) (Lepidoptera: Gelechiidae) is the South American tomato leafminer moth, which is invasive, devastating, and a major insect pest of tomato production in the world (Santana et al. 2019). Shiberu and Getu (2018) reported 78\% loss of tomato by this pest in Ethiopia. The larvae cause up to $100 \%$ tomato production losses if not controlled timely (Desneux et al. 2010) as well as expose plants to secondary infection by facilitating the entry of pathogens (Rwomushana et al. 2019).

Several types of synthetic insecticides have been attempted to control T. absoluta worldwide. However, the insect has become less responsive and highly resistant to synthetic insecticides (Roditakis et al. 2015). Hence, searching of ecofriendly alternatives for pest control has been taken as the most significant solution to minimize abovementioned problems. EPFs are parts of the potential alternatives. Attempts have been made for the search for effective EPF species to control T. absoluta (Ndereyimana et al. 2019). However, only one strain of $M$. anisopliae has been evaluated against $T$. absoluta in Ethiopia so far (Tadele and Emana 2017). Therefore, in the present study, 25 native Metarhizium isolates were recovered from different soil types, indexed for their biological efficiency, characterized by their morphological and molecular features, and evaluated for their pathogenicity against 2nd and 3rd larval instars of T. absoluta.

\section{Materials and methods}

\section{Sampling and sample collection}

Metarhizium species were isolated from 3 soil types: farmland, grazing land, and forest soils. Farm soil and grazing land soil were collected from central rift valley area of Ethiopia, particularly, from East Shewa Zone located at $7.3578^{\circ} \mathrm{N}$ and $38.4850^{\circ} \mathrm{E}$ coordinates in central Oromia that the tomato is extensively produced, using an irrigation system, and $T$. absoluta was highly manifested without a history of biopesticide application, whereas the forest soils were collected from Menagesha National Forest with geographic coordinates of $8.9782^{\circ} \mathrm{N}$ and $38.5585^{\circ} \mathrm{E}$ that covers the altitude between 2574 to 2948 masl and located $20 \mathrm{~km}$ west to the capital city, Addis Ababa, Ethiopia.

Rhizospheric soil were collected from tomato farms by uprooting of aged tomato plants, whereas grazing land and forest soils were taken from undisturbed places. All types of the soil were pooled from 5 to 15 $\mathrm{cm}$ depth by avoiding external parts and debris in triplicate diagonals of spots by considering $5 \mathrm{~m}$ apart from each spot of each site. Three replicates of the soil samples from each location were composited together and only $2 \mathrm{~kg}$ of mixed soils composed into ethanol-sterilized (70\%) plotline bag. Totally, 52 soil samples were collected from abovementioned sites and taken into Applied Microbiology Laboratory, Addis Ababa University (AAU) for further work. 


\section{Rearing of EPF susceptible insect}

The great wax moth (Galleria mellonella L.) was used for EPF trapping. The insect was reared at Ambo Plant Protection Research Center (APPRC), using the methods described by Meyling (2007). Briefly, 5 pairs of female and male moths were maintained in lid-capped 500-ml conical flasks containing strip-folded tissue paper infused with honey and kept for a week to facilitate mating and egg laying. After 1 week, the folded tissue paper with lied eggs was carefully transferred into insect rearing plastic container, filled with a mix of wheat bran $(100 \mathrm{~g})$, honey $(160 \mathrm{~g})$, and glycerol $(360 \mathrm{ml})$ as a food source for emerging larvae. Egg-inoculated rearing containers were incubated at $35{ }^{\circ} \mathrm{C}$ for 4 weeks until larvae were attained ages of appropriate instars of interest for EPF baiting.

\section{Rearing of $T$. absoluta}

The infected tomato leaves and fruits harboring larvae and pupae of T. absoluta collected from the central refit valley area using insect collection box were taken into greenhouse of AAU. The larvae and pupae were transferred into pot-grown tomato plants kept under zipped cages constructed from wooden poles and meshed cotton cloth. Pots with growing tomato plants were replaced in rearing cages once per 3 weeks for insect egg laying and for emerging larval feed. Infected tomato leaves in the rearing cages were inspected continuously for larval development and suitable larval instars were collected and used for EPF screening and pathogenicity bioassay.

\section{EPF isolation}

Metarhizium species were isolated from the soil using $G$. mellonella baiting method (Belay et al. 2017). Briefly, 3rd instar larvae of wax moth were shocked for $10 \mathrm{~s}$ in heat $\left(65{ }^{\circ} \mathrm{C}\right)$ warmed water to reduce extensive waving in the soil. One kilogram of soil samples moisturized by sterilized water was filled into $1 \frac{1 / 2}{2}$ capacity screw capped glass jar. Ten of heat-shocked wax moth larvae were introduced in to jars filled with soil samples separately and incubated at $28{ }^{\circ} \mathrm{C}$ for 10 days under complete dark condition. Larval death was inspected every 3 days and moisture content of the soil was adjusted by gentle moistening with sterile water each time following the inspection. The cadavers of dead larvae were carefully removed from the soil, surface sterilized by using sodium hypochlorite $(3 \%)$, followed by ethanol $(70 \%)$ for $10 \mathrm{~s}$ each, and rinsed 5 times with sterile water. Surfacesterilized larval cadavers were placed on sterile plastic plates lined with moistened tissue paper and incubated at room temperature until outgrown mycelia were sporulated under dark condition. The mycelial sporulation of EPF over the cadavers was checked, spores scraped by incinerated inoculating wire loop, transferred onto potato dextrose agar (PDA) medium, and incubated at 28 ${ }^{\circ} \mathrm{C}$ for 20 days. Isolates were purified by sub-culturing onto fresh PDA medium and pure cultures were maintained on agar slants at $4{ }^{\circ} \mathrm{C}$ for further work.

\section{Morphological identification}

Morphology of Metarhizium isolates were identified following the methods of Fernandes et al. (2010). The growth characteristics of isolates on the culture medium (PDA) was inspected continuously for 20 days and their colony size, mycelial color, colony reverse, and color of conidial mass were visualized. Spore feature characteristics of Metarhizium isolates particularly shape and size were examined using wet mount glass slide microscopic techniques, using light microscope (Fish Olympus phase contrast microscope).

\section{Prescreening of isolates \\ Spore germination potential}

Spore viability of isolates was checked through conidial germination test, using standard procedures (Habtegebriel et al. 2016). Fungal spores were collected from the 3 -week-old culture by scraping with a sterilized spatula. Collected spores were added into $10 \mathrm{ml}$ of sterile distilled water supplemented with Tween $80(0.1 \% \mathrm{v} / \mathrm{v})$ as a surfactant in falcon tube and evenly mixed through vortexing. Spore concentration was adjusted into $1 \times 10^{6}$ conidia $\mathrm{ml}^{-1}$ by using improved Neubauer hemocytometer under light microscope. A 100- $\mu$ l suspension was spread over the fresh PDA and 2 sterilized glass slides were laid over inoculated medium and incubated at $25{ }^{\circ} \mathrm{C}$ for $24 \mathrm{~h}$. After $24 \mathrm{~h}$ of incubation, over germination progresses of spores were halted by ethanol (70\%) dispensing. Then 100 spores of both germinated and non-germinated were counted, following the glass slides, using $\times 40$ magnifying objectives of light microscope and the experiment was repeated three times. Spores with germ tubes become high and then the spores itself were considered as germinated.

\section{Sporulation rate on the agar medium}

The sporulation rate of Metarhizium isolates was tested through plate culture method by incubating at $25{ }^{\circ} \mathrm{C}$ under complete dark condition. The plate cultures were checked daily for sporulation initiation since 4 days of initial inoculation. The sporulation rate of each isolate was recorded for 20 consecutive days and isolates that began to sporulate at the short time were considered as potential for pathogenicity screening procedure, using susceptible host, G. mellonella. Each plate served as a replicate and there were three replicates per isolates. 
Pathogenicity screening of isolates using G. mellonella The pathogenicity of isolates was evaluated using 3rd instar of G. mellonella larvae. Spores harvested from 3 weeks of old culture through sterilized spatula scraping were adjusted for conidial concentration at a maximum of $10^{8}$ spores $\mathrm{ml}^{-1}$ as explained above and $10 \mathrm{ml}$ of suspension were prepared with sterile water and Tween 80 $(0.1 \% \mathrm{v} / \mathrm{v})$ in sterilized falcon tube. Twenty larvae of $G$. mellonella were deepened into spore suspensions of each isolates for $15 \mathrm{~s}$ and transferred into sterile small jars filled with a mix of wheat bran $(25 \mathrm{~g})$, honey $(40 \mathrm{~g})$, and glycerol $(90 \mathrm{ml})$ separately. Treated larvae-containing jars were placed at room temperature for 10 days at dark conditions. Dead larvae were collected every 3 days, surface-sterilized, and transferred into sterilized plates lined with moistened tissue paper and incubated at room temperature in complete dark condition. The moisture content of the tissue paper was adjusted using sterile water spray to enhance mycelial outgrowth over the larval cadavers. The other 20 larvae were deepened into sterilized water with Tween $80(0.1 \% \mathrm{v} / \mathrm{v})$ as control and incubated at the same condition. Treatments were repeated 3 times to minimize uncertainty (Habtegebriel et al. 2016).

\section{Pathogenicity of isolates against $T$. absoluta}

Pathogenicity of 13 Metarhizium isolates prescreened by the cumulative biological efficiency index model was evaluated against 2nd and 3rd larval instars of T. absoluta (Sabbour and Singer 2014). Briefly, the spore suspensions of isolates were prepared into $1 \times 10^{7}$ conidia $\mathrm{ml}^{-1}$ consecration, using sterile water with Tween 80 $(0.1 \% \mathrm{v} / \mathrm{v})$. The tomato leaves were surface-sterilized using ethanol (70\%) disinfection for $3 \mathrm{~min}$ and rinsed 3 times with sterile distilled water. The tomato leaf petioles were tied by UV sterilized cotton wool to retain water and prevent leaf drying. The surface-sterilized leaves were maintained in sterile plastic plates and sprayed with $3 \mathrm{ml}$ of concentration-adjusted fungal spores and air-dried under the safety cabinet for $3 \mathrm{~min}$. Then 20 of each 2nd and 3rd larval instars of T. absoluta were released separately over the spore-sprayed leaves and incubated at room temperature for 7 days. The other 20 larvae of each instar of $T$. absoluta were released over surface-sterilized leaves sprayed with Tween $80(0.1 \% \mathrm{v} / \mathrm{v})$ plus water and incubated in the same condition as a control. Mortality of larvae was checked daily and dead larvae were surface-sterilized and transferred into other sterile plastic plates containing moisten tissue paper. Plates with larval cadaver were incubated at room temperature in dark conditions until developing the mycosis (Sabbour and Singer 2014). These cultures were maintained for 20 days on the plate to determine spore concentration per larval cadavers from the 3rd instar of larvae by using spore washing and microscopic counting method.

\section{Dose response of isolates to $T$. absoluta}

The concentrations $\left(\mathrm{LC}_{50}\right.$ and $\left.\mathrm{LC}_{90}\right)$ of mortality response and time taken to kill $50 \%\left(\mathrm{LT}_{50}\right)$ for 6 of the most virulent Metarhizium isolates were evaluated (Tefera and Pringle 2004). The stock spore suspensions of each isolate were prepared in sterile distilled water containing Tween $80(0.1 \% \mathrm{v} / \mathrm{v})$. Concentrations were down-adjusted to $1 \times 10^{4}, 1 \times 10^{5}, 1 \times 10^{6}, 1 \times 10^{7}$, and $1 \times 10^{8}$ spore $\mathrm{ml}^{-1}$ and evaluated for the 3rd instar of larvae, following the same procedure as described for pathogenicity assay. Twenty larvae were used for each concentration and control. Fungal infections of the dead larvae were confirmed after the outgrowth of mycosis on the cadavers. Mortality of larvae was recorded daily for 10 days, but lethal time calculation was performed only for three intermediate concentrations $\left(1 \times 10^{4}, 1 \times 10^{6}\right.$, and $1 \times 10^{8}$ spore $\mathrm{ml}^{-1}$ ) and all treatments were replicated 3 times.

\section{Molecular characterization of EPF isolates DNA extraction}

The genomic DNA of the fungi was extracted from 4 days old mycelial culture grown on potato dextrose agar, using a quick and safe fungal DNA extraction method (Chi et al. 2009). Approximately $400 \mathrm{mg}$ of mycelia grown on the PDA was transferred into $1.5 \mathrm{ml}$ Eppendorf tube containing $0.5 \mathrm{ml}$ of DNA extraction buffer (1 $\mathrm{M} \mathrm{KCl} ; 100 \mathrm{mM}$ Tris-HCl; $10 \mathrm{mM}$ EDTA) using a sterile toothpick. Soon after mycelia transfer, mycelial tissue was pulverized by using sterile plastic pestle fitted with an electronic instrument Black and Decker portable electronic drill (American manufacturer of power tools, Stanley Black \& Decker, Inc.) for 2 to $3 \mathrm{~s}$. Mycelial lysates were centrifuged at $12,000 \mathrm{~g}$ for $10 \mathrm{~min}$ in order to separate cell debris and contaminants from the supernatant. The DNA containing supernatant was carefully transferred into another $1.5 \mathrm{ml}$ Eeppendorf tubes containing $0.3 \mathrm{ml}$ of 2-propanol and mixed through tube inverting and centrifuged at 13,000 $\mathrm{g}$ for $10 \mathrm{~min}$. After discarding the supernatant, pellet in the Eppendorf tube was gently washed with $0.7 \mathrm{ml}$ of ethanol $(70 \%)$ and allowed for ethanol evaporation at room temperature for $15 \mathrm{~min}$. Then DNA pellet was dissolved by using $100 \mu \mathrm{l}$ of $20 \mathrm{mM}$ Tris solution through gentle tapping and stored at $-20{ }^{\circ} \mathrm{C}$ for PCR use. The DNA amount in the suspension was quantified by transferring $2 \mu \mathrm{l}$ of aliquots on to nano-drop microplates in duplicate using an instrument, BioTek Synergy ${ }_{2}{ }^{\mathrm{TM}}$ Multi-mode Microplate Reader controlled by Gen $5^{\mathrm{TM}}$ Dada analysis software, USA. Furthermore, DNA purity was confirmed by 
running PCR products under $1 \%$ agarose gel electrophoresis.

\section{PCR amplification}

The PCR amplification of DNA was performed by using ITS1 and ITS4 primers. Primers ITS1 TCCGTAGGTG AACCTGCGG forward and ITS4 TCCTCCGCTT ATTGATATGC reverse were used to amplify the target regions (White et al. 1990). The PCR amplification reaction was conducted in a total volume of $20 \mu \mathrm{l}$. The master mix was prepared from the components of $6.8 \mu \mathrm{l}$ of water, $4 \mu \mathrm{l}$ of buffer, $1 \mu \mathrm{l}\left(2.5 \mathrm{mM} \mathrm{\mu l}^{-1}\right) \mathrm{MgCl}_{2}, 1 \mu \mathrm{l}(0.5$ $\left.\mathrm{mM} \mathrm{l}^{-1}\right)$ of dNTP, $0.2 \mu \mathrm{l}\left(1 \mathrm{U}^{-1}\right)$ of GoTaq polymerase, $2.5 \mu \mathrm{l}\left(2.5 \mu \mathrm{M} \mathrm{\mu l}{ }^{-1}\right)$ of each ITS1 (forward) and ITS4 (reverse) primers, and $1 \mu \mathrm{l}\left(30 \mu \mathrm{g}^{-1}\right)$ of genomic DNA. PCR thermocycler settings were $4 \mathrm{~min}$ initial denaturation at $94{ }^{\circ} \mathrm{C}$ followed by 35 cycles of 1 min denaturation at $94{ }^{\circ} \mathrm{C}, 1 \mathrm{~min}$ annealing at $56{ }^{\circ} \mathrm{C}$, and $1 \mathrm{~min}$ extension at $72{ }^{\circ} \mathrm{C}$. The final extension was performed at $72{ }^{\circ} \mathrm{C}$ for $5 \mathrm{~min}$ with a storage temperature of $4{ }^{\circ} \mathrm{C}$. The PCR products were assayed by electrophoresis on a $2.5 \%$ agarose gel with TBE buffer (Tris; Borate; EDTA) at 100 $\mathrm{V}$ for $55 \mathrm{~min}$. Then the gel was stained by shaking within $200 \mathrm{ml}$ of TBE buffer supplemented with $10 \mu \mathrm{l}(\mathrm{v} / \mathrm{v})$ of non-carcinogenic dye "SafeView ${ }^{\mathrm{TM}}$ Plus" for $50 \mathrm{~min}$ and photographed under UV light using eight-mega pixels canon pc1201 digital camera. The PCR amplicons amplified in a volume of $50 \mu \mathrm{l}$ was purified by using NucleoSpin $^{\circ}$ Gel and PCR Clean-upkits (Germany), checked for DNA purity using $2.5 \%$ agarose gel electrophoresis, and send to Macrogen Inc. Seoul, Korea for sequencing.

\section{Data analysis}

The obtained data for larval mortality were calculated by using Abbott's formula (Abbott 1925). Spore germination, sporulation date, and screening test results were analyzed by using one-way of variance (ANOVA) using SPSS software version 25 statistical programs. Mean separations were calculated using Tukey's HSD test when the value were significant at $=0.05$. The relative sporulation rate (RSR) of the isolates was calculated using the formula RSR $=\frac{\text { Exprimental lasting date }}{\text { PCS date of isolate }}$ where PCS, plate culture sporulation, and biological efficacy (BE) index were computed by using the biological indexing formula of Sain et al. (2019) with some modification: $\mathrm{BE}$ index $(\%)=37(\mathrm{SG})+13(\mathrm{RSR})+50(\mathrm{LM})$ where SG, spore germination and LM, larval mortality in 7 days post inoculation of spores. Lethal concentration $\left(\mathrm{LC}_{50}\right.$ and $\mathrm{LC}_{90}$ ) was analyzed by using Probit analysis software in SPSS version 25. The dose responses of each replicate were checked for estimation of lethal time to kill 50\% $\left(\mathrm{LT}_{50}\right)$ of exposed larvae. Analysis of variances and means were separated by using least significant differences (LSD).

\section{Results and discussion}

In this study, 25 Metarhizium isolates were isolated from the soil by using G. mellonella baiting method (Table 1). The total isolates trapped from the collected soil samples by insect baiting was $48 \%$. The preliminary characterization showed that all of these isolates produced typical greenish conidial masses of Metarhizium on the culture plate with smooth plate reverses (Fig. 1). Such cultural morphology was an important preface distinguishing attributes to identify the intended EPF from the other relatives ( $\mathrm{Du}$ et al. 2019). Furthermore, microscopic examination of spore features (spore shape and size) supported partial identification of the isolates. Obtained isolates produced intermediate and small-sized and ellipsoid spores (Fig. 1). Sometimes, spore features of Metarhizium strains may vary in color and size (Tangthirasunun et al. 2010) as recognized in this study.

The distribution and occurrence of isolates per soil types were $52 \%$ in the farm soil, $36 \%$ in the grazing land soil, and the remaining $12 \%$ in the forest soil (Fig. 2a). Sometimes, EPF could be abundant in the farm soil (Stranne 2014), especially Metarhizium spp. dominated in agricultural habitat (Sánchez-Peña et al. 2011). Remixing of the soil during land plowing could allow better distribution of fungal propagules or contentious pest and entomopathogens interaction through natural dynamics may increase the fungal abundance in the farm soil (Vega et al. 2012). Moreover, as our soil samples collected from irrigation farm, sufficient moisture content of the source may favor spore germination to stay propagules alive.

The biological efficiency (BE) index model was emanated as a promising approach for EPF screening (Sain et al. 2019). The data computed by BE indexing model was prescreened 13 (52\%) candidates from 25 isolates considering three main biological aspects, spore viability, sporulation rate, and their pathogenicity potential to hosts. In fact, most of the isolates showed statistically significant differences for each criterion, but these abovementioned isolates scored cumulative $\mathrm{BE}$ index values of above $80 \%$ and screened as efficient candidates as asterisks $\left(^{*}\right)$ (Table 1). The 2 isolates (AAUM40 and AAUM12) showed superior (85.6 and $85.74 \%$ ) cumulative BE index; however, the other eleven scored between 80.75 and $84.85 \%$, respectively. Several reports emphasized that strains with best spore germination potential (Posada and Vega 2005), fast sporulation rate (Mar et al. 2012), and high virulence to their host (Saleh et al. 2016) are important criteria for selecting promising candidates for agriculturally important pest control. 
Table 1 Prescreening and biological efficiency index calculation of isolates based on spore germination, culture sporulation dates, and larval mortality of Galleria mellonella at $1 \times 10^{8}$ spore $\mathrm{ml}^{-1}$ in 10 days of post inoculation

\begin{tabular}{|c|c|c|c|c|c|c|c|}
\hline Isolates & Genera & Source (soil) & SG (\%) $\pm S D$ & Mean of DPCS \pm SD & RSR & $L M(\%) \pm S D$ & BE index (\%) \\
\hline$\overline{\text { AAUM46* }}$ & Metarhizium & Farm & $92.66 \pm 2.51^{\mathrm{ab}}$ & $12.83 \pm 1.52^{\mathrm{ab}}$ & 1.559 & $93.33 \pm 11.54^{\mathrm{ab}}$ & $81.15^{b}$ \\
\hline AAUM32* & Metarhizium & Grazing & $89.00 \pm 2.64^{b c}$ & $14.00 \pm 1.32^{c}$ & 1.429 & $100 \pm 0.00^{a}$ & $83.12^{\mathrm{ab}}$ \\
\hline AAUM30* & Metarhizium & Grazing & $96.33 \pm 1.52^{\mathrm{a}}$ & $12.33 \pm 1.52^{\mathrm{ab}}$ & 1.622 & $98.00 \pm 2.00^{b}$ & $84.85^{\mathrm{a}}$ \\
\hline AAUM01 & Metarhizium & Farm & $94.00 \pm 3.00^{\mathrm{ab}}$ & $14.33 \pm 0.57^{b c}$ & 1.397 & $87.66 \pm 0.2 .08^{c}$ & $78.79^{b c}$ \\
\hline AAUM17 & Metarhizium & Farm & $94.00 \pm 2.00^{\mathrm{ab}}$ & $14.00 \pm 2.00^{c}$ & 1.429 & $83.00 \pm 6.08^{\mathrm{dc}}$ & $76.47^{c}$ \\
\hline AAUM28 & Metarhizium & Grazing & $90.00 \pm 3.60^{b}$ & $15.33 \pm 1.52^{\mathrm{cd}}$ & 1.305 & $86.00 \pm 1.45^{b}$ & $76.47^{c}$ \\
\hline AAUM22 & Metarhizium & Farm & $92.33 \pm 3.51^{\mathrm{ab}}$ & $16.00 \pm 2.00^{d}$ & 1.250 & $86.66 \pm 5.77^{d c}$ & $77.65^{c}$ \\
\hline AAUM10 & Metarhizium & Farm & $65.00 \pm 48.50^{\mathrm{ef}}$ & $13.50 \pm 2.29^{b}$ & 1.481 & $88.33 \pm 11.06^{c}$ & $68.41^{e}$ \\
\hline AAUM39* & Metarhizium & Grazing & $91.66 \pm 2.51^{b}$ & $13.50 \pm 3.50^{\mathrm{ab}}$ & 1.481 & $100 \pm 0.00^{\mathrm{a}}$ & $84.11^{\mathrm{a}}$ \\
\hline AAUM20* & Metarhizium & Forest & $92.33 \pm 2.08^{\mathrm{ab}}$ & $11.66 \pm 1.52^{\mathrm{ab}}$ & 1.715 & $98.33 \pm 2.88^{\mathrm{a}}$ & $83.55^{\mathrm{ab}}$ \\
\hline AAUM42 & Metarhizium & Forest & $74.00 \pm 11.13^{d}$ & $14.00 \pm 1.00^{c}$ & 1.426 & $73.33 \pm 5.77^{f}$ & $64.23^{\mathrm{ef}}$ \\
\hline AAUM14 & Metarhizium & Farm & $69.66 \pm 6.65^{e}$ & $14.00 \pm 2.00^{c}$ & 1.429 & $93.00 \pm 6.55^{b}$ & $72.46^{d}$ \\
\hline AAUM40* & Metarhizium & Farm & $95.66 \pm 3.21^{a}$ & $12.83 \pm 0.76^{\mathrm{ab}}$ & 1.559 & $100 \pm 0.00^{a}$ & $85.60^{\mathrm{a}}$ \\
\hline AAUM43* & Metarhizium & Grazing & $92.00 \pm 3.60^{\mathrm{ab}}$ & $12.63 \pm 2.12^{\mathrm{ab}}$ & 1.584 & $93.00 \pm 2.00^{b}$ & $80.75^{\mathrm{b}}$ \\
\hline AAUM76** & Metarhizium & Forest & $92.00 \pm 6.08^{\mathrm{ab}}$ & $11.16 \pm 0.76^{\mathrm{ab}}$ & 1.792 & $96.66 \pm 5.77^{\mathrm{ab}}$ & $82.60^{\mathrm{ab}}$ \\
\hline AAUM12* & Metarhizium & Grazing & $96.00 \pm 3.60^{a}$ & $12.00 \pm 2.00^{\mathrm{ab}}$ & 1.667 & $100 \pm 0.00^{\mathrm{a}}$ & $85.74^{a}$ \\
\hline AAUM66 & Metarhizium & Grazing & $59.00 \pm 8.88^{e f}$ & $14.00 \pm 1.73^{c}$ & 1.429 & $86.66 \pm 11.54^{\mathrm{de}}$ & $65.35^{\mathrm{e}}$ \\
\hline AAUM21* & Metarhizium & Grazing & $91.66 \pm 2.51^{b}$ & $13.50 \pm 3.12^{b}$ & 1.481 & $93.33 \pm 5.77^{b}$ & $80.77^{\mathrm{b}}$ \\
\hline AAUM08 & Metarhizium & Farm & $76.66 \pm 3.05^{\mathrm{de}}$ & $15.33 \pm 0.57^{d}$ & 1.305 & $53.33 \pm 5.77^{g h i}$ & $55.20^{\mathrm{fgh}}$ \\
\hline AAUM78* & Metarhizium & Grazing & $90.33 \pm 2.51^{b}$ & $12.00 \pm 1.00^{\mathrm{ab}}$ & 1.667 & $100 \pm 0.00^{\mathrm{a}}$ & $83.64^{a}$ \\
\hline AAUM04 & Metarhizium & Farm & $88.00 \pm 2.00^{c d}$ & $14.66 \pm 1.15^{c}$ & 1.364 & $90.00 \pm 0.00^{b}$ & $77.74^{c}$ \\
\hline AAUM44 & Metarhizium & Farm & $80.66 \pm 6.11^{c}$ & $13.33 \pm 1.52^{b}$ & 1.500 & $80.00 \pm 1.00^{\mathrm{de}}$ & $70.04^{d}$ \\
\hline AAUM16 & Metarhizium & Farm & $86.66 \pm 3.05^{\mathrm{cd}}$ & $13.00 \pm 1.00^{b}$ & 1.538 & $86.66 \pm 11.54^{\mathrm{de}}$ & $75.59^{c}$ \\
\hline AAUM80* & Metarhizium & Farm & $91.66 \pm 2.51^{\mathrm{ab}}$ & $13.66 \pm 1.52^{b}$ & 1.464 & $93.33 \pm 5.77^{\mathrm{b}}$ & $80.77^{b}$ \\
\hline AAUM06* & Metarhizium & Farm & $91.33 \pm 3.05^{\mathrm{ab}}$ & $13.20 \pm 3.12^{b}$ & 1.515 & $100 \pm 0.00^{\mathrm{a}}$ & $83.99^{\mathrm{a}}$ \\
\hline
\end{tabular}

Letters in the columns ( $a, b, c, d, e, f, g$, and $h$ ) are ranks of the mean

$D P C S$ date of plate culture sporulation, SG spore germination, $L M$ larval mortality, SD standard deviation, RSR, relative sporulation rating, BE biological efficiency *Selected isolates

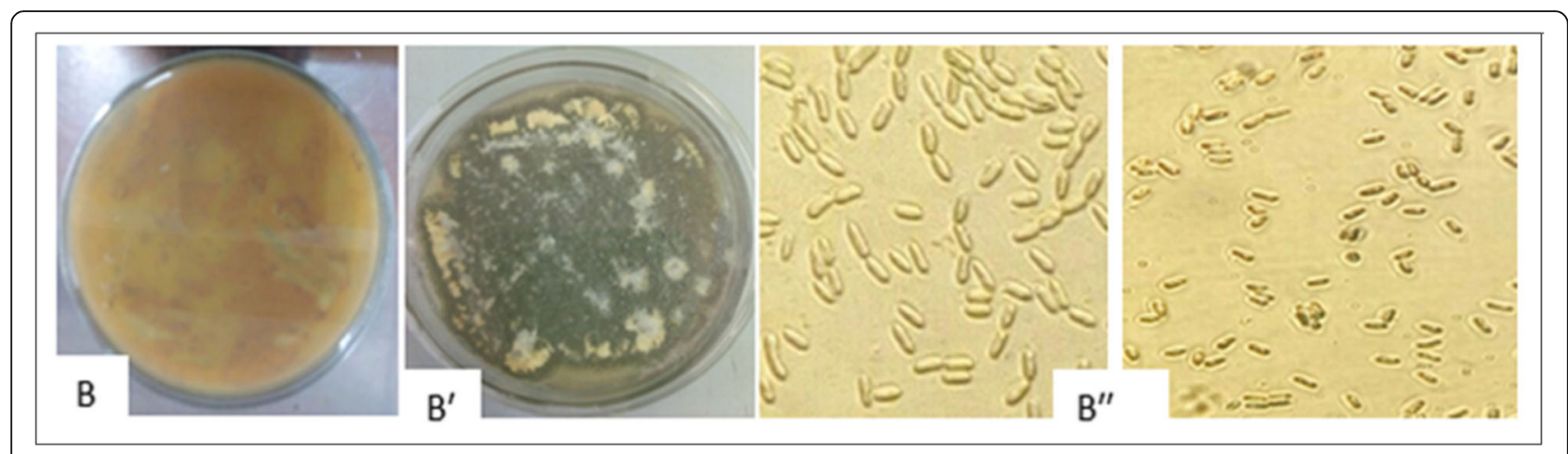

Fig. 1 Reverse (B) and front (B') view of plate culture and spore structures ( $\left.\mathbf{B}^{\prime \prime}\right)$ of Metarhizium anisopliae 

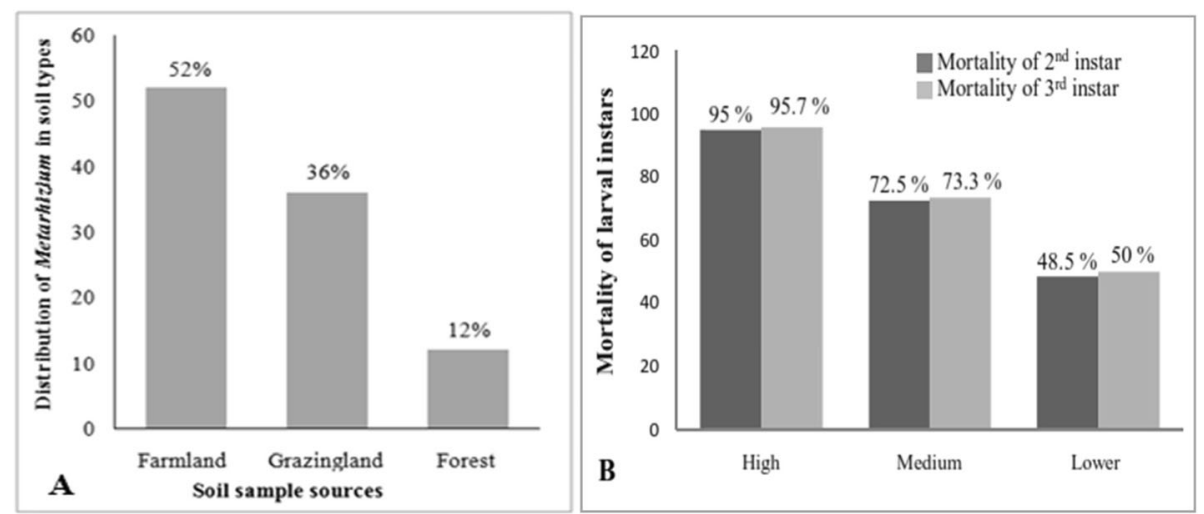

Fig. 2 Distribution of Metarhizium in the soil types (a) and summary of Metarhizium pathogenicity potential against 2nd and 3rd larval instars of Tuta absoluta (b)

Pathogenicity test revealed that most of these prescreened isolates were effective against $T$. absoluta with a spore concentration of $10^{7}$ spore $\mathrm{ml}^{-1}$ in 7 days of post inoculation (Table 2). Maximum, medium, and low mortality rates caused by Metarhizium isolates on both 2nd and 3rd larval instars of $T$. absoluta were almost the same (Fig. 2b). However, mean pathogenicity among isolates showed marked difference with statistical values of $F(23,15)=3.97, p<0.001$ for 3rd instar and $F(24,50)$ $=6.825, p<0.001$ for 2nd instar of larvae. The death of larvae by Metarhizium was ensured through green muscardine production on the cadavers.

Among the evaluated isolates, $23 \%$ showed markedly high mortality rates (90 to $95.66 \%$ ), 30.8\% scored high mortality ( 81.66 to $88.33 \%$ ), and $38.5 \%$ caused modest mortality (73.33 to $76.66 \%)$; however, only one isolate scored relatively low (50\%) mortality rate on the 3rd larval instar of $T$. absoluta (Table 2). The isolates AAUM78 and AAUM39 exhibited the highest pathogenicity on the 2nd larval instar of $T$. absoluta with mortality rate of 90 and 95\%, respectively. However, other isolates showed relatively reduced virulence against 2nd larval instar than 3rd ones. The data clearly indicated that some of the isolates were as effective as the commercially formulated Metarhizium (Metatech $^{\circ}$ WP) that caused $82.8 \%$ larval mortality of T. absoluta at $10^{8}$ spores $\mathrm{ml}^{-1}$ in Rwanda (Ndereyimana et al. 2019), with $87.5 \%$ mortality recorded from the treatment of $2.5 \times 10^{9}$ spores $\mathrm{ml}^{-1}$ of $M$. anisopliae in Ethiopia (Tadele and Emana 2017).

Table 2 Rescreening of pathogenically potential isolates against second and third larval instars of Tuta absoluta at $1 \times 10^{7}$ spore $\mathrm{ml}^{-1}$ for 7 days exposure and sporulation potential over cadavers

\begin{tabular}{|c|c|c|c|c|}
\hline Screened isolates & Genus & 2nd instar $\mathrm{LM}(\%) \pm \mathrm{SD}$ & 3rd instar LM (\%) $\pm S D$ & Spore conc. per cadaver $\mathrm{ml}^{-1}$ \\
\hline AAUM30 & Metarhizium & $48.47 \pm 2.00^{j}$ & $50.00 \pm 10.00^{h}$ & $8.4 \times 10^{5}$ \\
\hline AAUM43 & Metarhizium & $86.66 \pm 7.63^{b}$ & $81.66 \pm 2.88^{\mathrm{bc}}$ & $3.2 \times 10^{6}$ \\
\hline AAUM76 & Metarhizium & $88.00 \pm 10.00^{b}$ & $95.66 \pm 5.77^{\mathrm{a}}$ & $3.1 \times 10^{7}$ \\
\hline AAUM06 & Metarhizium & $56.52 \pm 3.56^{h}$ & $75.00 \pm 15.00^{c}$ & $9.6 \times 10^{5}$ \\
\hline AAUM32 & Metarhizium & $66.52 \pm 3.56^{\mathrm{ef}}$ & $75.34 \pm 39.00^{c}$ & $2.4 \times 10^{5}$ \\
\hline AAUM80 & Metarhizium & $83.33 \pm 7.63^{b c}$ & $83.33 \pm 15.27^{b}$ & $7.9 \times 10^{6}$ \\
\hline AAUM12 & Metarhizium & $72.54 \pm 6.68^{d}$ & $73.33 \pm 10.40^{c d}$ & $1.5 \times 10^{6}$ \\
\hline AAUM46 & Metarhizium & $69.02 \pm 4.82^{e}$ & $76.66 \pm 14.43^{c}$ & $4.8 \times 10^{6}$ \\
\hline AAUM20 & Metarhizium & $89.00 \pm 5.00^{b}$ & $86.66 \pm 11.54^{b}$ & $4.7 \times 10^{6}$ \\
\hline AAUM40 & Metarhizium & $73.33 \pm 7.63^{d}$ & $88.33 \pm 7.63^{\mathrm{ab}}$ & $4.4 \times 10^{6}$ \\
\hline AAUM78 & Metarhizium & $90.00 \pm 5.00^{\mathrm{a}}$ & $90.00 \pm 10.00^{\mathrm{ab}}$ & $5.4 \times 10^{7}$ \\
\hline AAUM39* & Metarhizium & $95.00 \pm 8.66^{\mathrm{a}}$ & $93.33 \pm 5.77^{\mathrm{a}}$ & $1.8 \times 10^{7}$ \\
\hline AAUM21 & Metarhizium & $69.23 \pm 2.12^{\mathrm{e}}$ & $75.00 \pm 15.00^{c}$ & $4.9 \times 10^{5}$ \\
\hline
\end{tabular}

Letters in the columns ( $a, b, c, d, e, f, g$, and $h$ ) are ranks of the mean LM larval mortality, SD standard deviation

Reselected isolates 


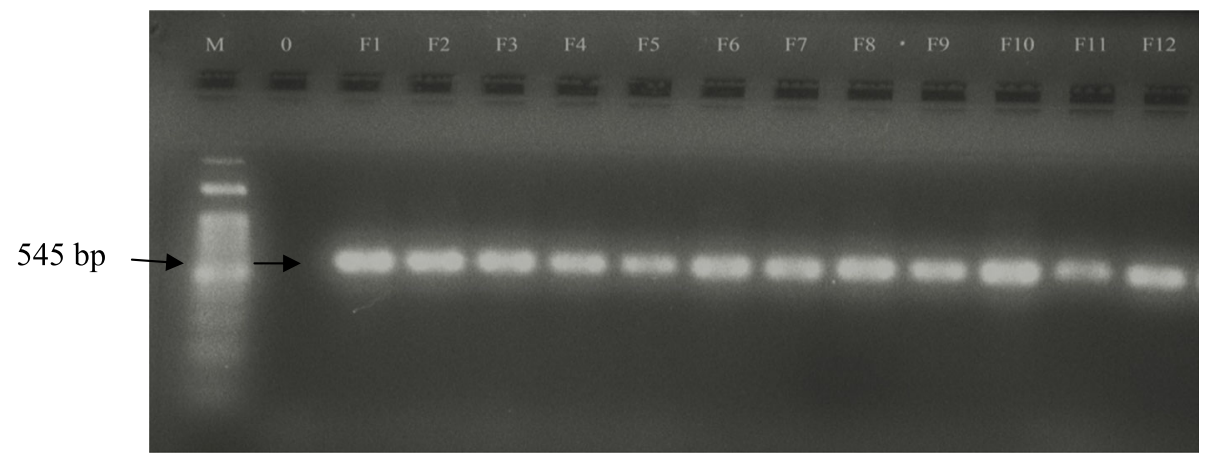

Fig. 3 PCR products amplified using ITS primers (ITS1 and ITS4) from twelve potential isolates of Metarhizium anisopliae. M, 1000 bp ladder; 0 , blank; F1 up to F12 was AAUM78, AAUM12, AAUM30, AAUM76, AAUM40, AAUM39, AAUM43, AAUM80, AAUM06, AAUM21, AAUM32, and AAUM20, respectively

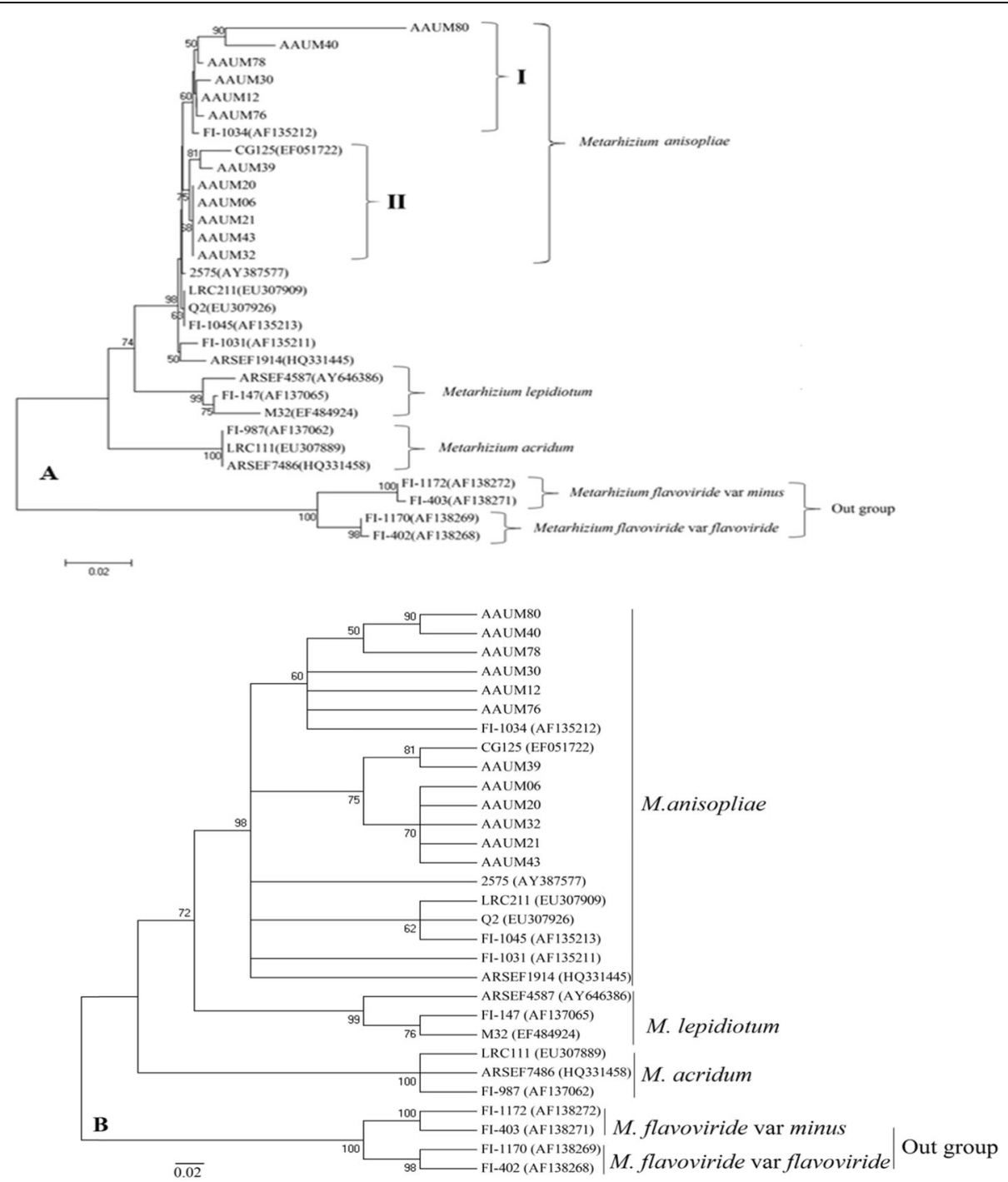

Fig. 4 Molecular phylogenic (a) and cladogram (b) analysis of ITS region of Metarhizium anisopliae from Ethiopia and other related sequences retrieved from gene Bank. Maximum likelihood phylogenetic tree (MEGA4.1) based on ITS sequences from Metarhizium species using K2pl model, with 1000 bootstrap replications. Bootstrap values above 50\% shown and corresponding accession number of strains were presented 
In this study, maximum and minimum mortality rates on both 2nd larval instar attained 95 and 93\%, respectively, at the isolate AAUM39 and 48.47 and 50\%, respectively, at AAUM30 (Table 2). Different studies showed that Metarhizium had a high virulence against 3rd larval instar of T. absoluta (Alikhani et al. 2019; Ndereyimana et al. 2019).

Meanwhile, the most pathogenic fungal isolates produced promising spores over larval cadavers with minimum $\left(3.2 \times 10^{6}\right.$ spore $\left.\mathrm{ml}^{-1}\right)$ to maximum $\left(5.4 \times 10^{7}\right.$ spores $\mathrm{ml}^{-1}$ ) concentration as indicated by a diamond ( $\downarrow$ in Table 2. The isolates that achieved high pathogenicity on both larval instars of the pest and had better sporulation are potential candidates to develop mycoinsecticides in the future. Especially, the mortality of T. absoluta at the early stage was vital to reduce extensive crop damages (Pires et al. 2010). Furthermore, fast sporulation entomopathogens with a large amount of spore production over the cadavers might give enhanced horizontal pest infection through swift selfdissemination (Conceschi et al. 2016).

Amplification of internal transcribed spacer (ITS1-5.8SITS4) rDNA regions of the 12 selected isolates showed DNA with an approximate size of 545 bp (Fig. 3). DNA sequencing and phylogenic analysis tentatively positioned these isolates in to M. anisopliae species (Fig. 4), in which the topology was similar to that described by other authors (Brancini et al. 2018). Relationship check was assured by BLAST search method and all of the isolates that have $99 \%$ and above similarity with sequence of M. anisopliae species quarried from GenBank. Interestingly, this main node is divided into 2 subgroups (I and II), with a percentage of statistical support bootstrap of 60 and $75 \%$, respectively (Fig. 4a). Group I contained a sample of the data bank corresponding to AF135212 and group II to sample EF051722 (Fig. 4a, b). Although the statistical support is not as robust for both groups, it would be very interesting to see if the samples within each group have any genetic, biological, and/or entomopathogenic characteristics in common. Something similar could happen in the case of samples AAUM80 and AAUM40, which have a high bootstrap (90\%) and sample AUM39 with the sample from data bank EF051722.

The efficacy of all isolates increased as concentration and exposure time was increased (Table 3). However, the median lethal time taken to kill $50 \%\left(\mathrm{LT}_{50}\right)$ was significantly different between isolates at $P=0.05$ (Table 3). The $\mathrm{LT}_{50}$ of the isolates was between 3.5 and 5.33 days at low $\left(10^{4}\right.$ spore $\left.\mathrm{ml}^{-1}\right)$ spore concentration against 3rd larval instar of T. absoluta, whereas $\mathrm{LT}_{50}$ of 1.93 and 2.98 days was scored at high $\left(10^{8}\right.$ spore $\left.\mathrm{ml}^{-1}\right)$ spore concentration, respectively. The two best isolates, AAUM78 and AAUM39, displayed $\mathrm{LT}_{50}$ of 3.93 and 3.5 days at low $\left(10^{4}\right.$ spores $\left.\mathrm{ml}^{-1}\right)$ concentration and 1.93 and 2.8

Table 3 Summary of Probit analysis, calculated lethal time, and concentration-mortality response at 10 days of post inoculation to third larval instar of Tuta absoluta

\begin{tabular}{|c|c|c|c|c|c|c|}
\hline Spore $\mathrm{ml}^{-1}$ & AAUM43 & AAUM76 & AAUM20 & AAUM80 & AAUM78 & AAUM39 \\
\hline \multicolumn{7}{|c|}{ Mortality (mean \pm SE) } \\
\hline $10^{4}$ & $50.33 \pm 4.41^{\mathrm{e}}$ & $52.33 \pm 4.41^{e}$ & $50.00 \pm 5.77^{e}$ & $55.00 \pm 2.89^{e}$ & $78.33 \pm 4.41^{\mathrm{a}}$ & $65.00 \pm 10.41^{c}$ \\
\hline $10^{5}$ & $61.67 \pm 10.1^{c}$ & $61.67 \pm 6.01^{c}$ & $61.67 \pm 4.41^{c}$ & $60.00 \pm 5.77^{c}$ & $83.33 \pm 1.67^{\mathrm{ab}}$ & $73.33 \pm 4.41^{b c}$ \\
\hline $10^{6}$ & $81.67 \pm 3.33^{b}$ & $70.00 \pm 5.77^{d}$ & $83.33 \pm 6.01^{b c}$ & $76.67 \pm 4.41^{c}$ & $86.67 \pm 1.67^{b}$ & $83.33 \pm 1.67^{b c}$ \\
\hline $10^{7}$ & $95.00 \pm 1.89^{\mathrm{a}}$ & $80.00 \pm 5.00^{b c}$ & $89.00 \pm 2.89^{\mathrm{ab}}$ & $88.33 \pm 1.67^{b}$ & $93.33 \pm 1.67^{\mathrm{a}}$ & $91.33 \pm 1.67^{b}$ \\
\hline $10^{8}$ & $95.00 \pm 0.00^{\mathrm{a}}$ & $86.67 \pm 1.67^{c}$ & $91.67 \pm 1.67^{b}$ & $90.00 \pm 2.89^{b}$ & $96.67 \pm 1.67^{\mathrm{a}}$ & $93.33 \pm 1.67^{\mathrm{ab}}$ \\
\hline \multicolumn{7}{|c|}{$\mathrm{LT}_{50}($ mean $\pm \mathrm{SE})$} \\
\hline $10^{4}$ & $5.33 \pm 0.58^{c}$ & $4.00 \pm 1.00^{b}$ & $4.00 \pm 1.00^{b}$ & $4.00 \pm 1.00^{b}$ & $3.93 \pm 0.90^{\mathrm{ab}}$ & $3.50 \pm 0.50^{\mathrm{a}}$ \\
\hline $10^{6}$ & $3.00 \pm 0.00^{b}$ & $3.60 \pm 0.53^{\mathrm{a}}$ & $3.33 \pm 0.58^{b}$ & $3.87 \pm 0.12^{\mathrm{ab}}$ & $3.33 \pm 0.58^{b}$ & $3.00 \pm 0.00^{b}$ \\
\hline $10^{8}$ & $2.81 \pm 0.00^{b}$ & $2.98 \pm 0.00^{\mathrm{a}}$ & $2.87 \pm 0.12^{b}$ & $2.93 \pm 0.12^{\mathrm{a}}$ & $1.93 \pm 0.00^{\mathrm{a}}$ & $2.80 \pm 0.20^{b}$ \\
\hline \multicolumn{7}{|c|}{ Summary of Probit analysis } \\
\hline$L C_{50}$ & $1.4 \times 10^{4}$ & $7 \times 10^{4}$ & $4.3 \times 10^{4}$ & $4.1 \times 10^{4}$ & $1.2 \times 10^{3}$ & $2.9 \times 10^{3}$ \\
\hline $95 \% \mathrm{FL}$ & $4 \times 10^{3}-7.2 \times 10^{4}$ & $2.8 \times 10^{3}-3.6 \times 10^{5}$ & $3.8 \times 10^{3}-1.7 \times 10^{5}$ & $2.5 \times 10^{3}-1.8 \times 10^{5}$ & $8.3 \times 10^{2}-3.8 \times 10^{3}$ & $1.9 \times 10^{2}-2.9 \times 10^{4}$ \\
\hline $\mathrm{LC}_{90}$ & $8.2 \times 10^{6}$ & $1.7 \times 10^{8}$ & $1.6 \times 10^{7}$ & $2.8 \times 10^{7}$ & $3.5 \times 10^{6}$ & $7.1 \times 10^{6}$ \\
\hline $95 \% \mathrm{FL}$ & $1.6 \times 10^{6}-3.6 \times 10^{7}$ & $1.6 \times 10^{7}-1.1 \times 10^{9}$ & $3.1 \times 10^{6}-4.5 \times 10^{8}$ & $4.6 \times 10^{6}-1.7 \times 10^{8}$ & $1.2 \times 10^{4}-3.4 \times 10^{6}$ & $1 \times 10^{6}-1.7 \times 10^{7}$ \\
\hline Int \pm SE & $1.93 \pm 0.66$ & $1.83 \pm 0.66$ & $2.32 \pm 0.64$ & $2.10 \pm 0.63$ & $0.59 \pm 0.80$ & $1.31 \pm 0.66$ \\
\hline$S \pm S E$ & $4.6 \pm 0.12$ & $3.8 \pm 0.10$ & $5 \pm 0.11$ & $4.5 \pm 0.11$ & $3.4 \pm 0.15$ & $3.8 \pm 0.12$ \\
\hline$P$ value & $<0.05$ & $<0.05$ & $<0.05$ & $<0.05$ & $<0.05$ & $<0.05$ \\
\hline
\end{tabular}

Letters in the columns ( $a, b, c, d$, and $\left.e_{1}\right)$ are ranks of the mean

$F L$ fiducial limit, SE standard error, $L T$ lethal time taken to kill $50 \%$ of experimental organisms, $L C$ lethal concentration, Int intercept, $S$ slope 
days at high $\left(10^{8}\right.$ spore $\left.\mathrm{ml}^{-1}\right)$ spore concentration, respectively. This was a better score than the commercial Metarhizium (Metatech ${ }^{\circ} \mathrm{WP}$ ) with $\mathrm{LT}_{50}$ of 3.9 days against larvae of $T$. absoluta at spore concentration of $10^{8}$ spores $\mathrm{ml}^{-1}$ in Rwanda (Ndereyimana et al. 2019) and 5.21 days with $2.5 \times 10^{9}$ spore $\mathrm{ml}^{-1}$ of $M$. anisopliae in Ethiopia (Tadele and Emana 2017).

Although some variations among the strains, all of the selected isolates showed promising $\operatorname{LC}_{50}\left(1.2 \times 10^{3}\right.$ spores $\mathrm{ml}^{-1}$ to $7 \times 10^{4}$ spores $\left.\mathrm{ml}^{-1}\right)$ and $\mathrm{LC}_{90}\left(3.5 \times 10^{6}\right.$ spores $\mathrm{ml}^{-1}$ to $1.7 \times 10^{8}$ spores $\mathrm{ml}^{-1}$ ) values (Table 3 ). Particularly, AAUM78 and AAUM39 showed $\mathrm{LC}_{50}$ of $1.2 \times 10^{3}$ and $2.9 \times 10^{3}$ and $\mathrm{LC}_{90}$ of $3.5 \times 10^{6}$ and $7.1 \times$ $10^{6}$, respectively (Table 3 ), and this indicated the effectiveness of these 2 strains. Isolates, effective at the lowest lethal concentration, are promising for T. absoluta management (Alikhani et al. 2019) with economical conidial mass production. Generally, researchers revealed the importance of best concentration and lethal time determination methods to select effective isolates for mycoinsecticidal formulations for field application against target insect pest (Sain et al. 2019).

\section{Conclusion}

The preset study revealed the possibility of isolate Metarhizium strains from the local environment to manage T. absoluta. Most of the M. anisopliae strains, especially the two strains AAUM78 and AAUM39, showed a high pathogenicity against larvae of $T$. absoluta. The strains with short $\mathrm{LT}_{50}$ and low $\mathrm{LC}_{50}$ values are promising to control the target pest at early stage as well as produce economical conidia for pest management. Further field evaluation of these strains is needed to determine their potential against $T$. absoluta.

\section{Abbreviations \\ EPF: Entomopathogenic fungi; APPRC: Ambo Plant Protection Research Center; AAU: Addis Ababa University; LT: Lethal time; LC: Lethal concentration; PCR: Polymerase chain reaction; \\ EDTA: Ethylenediaminetetraacetic acid; TBE: Tris-borate-EDTA; \\ ANOVA: Analysis of variance; BE: Biological efficiency; SG: Spore germination; DPCS: Date of plate culture sporulation; RSR: Relative sporulation rate; LM: Larval mortality; ITS: Internal transcribed spacer}

\section{Acknowledgements \\ We would like to acknowledge the financial support of "The Healthy Seedling Project" granted by both the Ethiopian Biotechnology Institute (EBtI) and the Regional Project supported by Austrian Development Agency $(\mathrm{ADA})$}

\section{Authors' contributions}

BA designed the study, conducted the laboratory experiment, performed data analysis, and drafted the manuscript. JV involved in molecular work, processed DNA sequencing, and performed molecular data analysis. FA and DM reviewed the manuscript and added their inputs. The authors read and approved the final manuscript.

\section{Funding}

Consumables (media, reagents, glasswares, and detergents), instruments, and required equipment were supported by EBtl granted healthy seedling project and international student fellowship program in the University of Chile.

\section{Availability of data and materials}

The analyzed datasets used in this study were included in the manuscript and the primary data was found with the corresponding author.

Ethics approval and consent to participate

Not applicable.

\section{Consent for publication}

Not applicable.

\section{Competing interests}

The authors declare that they have no competing interests.

\section{Author details}

${ }^{1}$ Institute of Biotechnology, Addis Ababa University, Addis Ababa, Ethiopia. ${ }^{2}$ Faculty of Medicine, Institute of Biomedical Sciences, Cellular and Molecular Biology Program, University of Chile, Santiago, Chile. ${ }^{3}$ College of Natural and Computational Sciences, Department of Microbial, Cellular and Molecular Biology, Addis Ababa University, Addis Ababa, Ethiopia.

Received: 18 March 2020 Accepted: 5 May 2020

Published online: 18 May 2020

\section{References}

Abbott WS (1925) A method of computing the effectiveness of an insecticide. J Econ Entomol 18:265-267

Alikhani M, Safavi AS, Iranipour S (2019) Effect of the entomopathogenic fungus, Metarhizium anisopliae (Metschnikoff) Sorokin, on demographic fitness of the tomato leaf miner, Tuta absoluta (Meyrick) (Lepidoptera: Gelechiidae). Egypt $J$ Biol Pest Control 29:1-7

Belay CY, Meressa HB, Alemu T, Hallmann J (2017) Molecular detection of the entomopathogenic fungus Beauveria bassiana from soils of coffee growing areas in Ethiopia using rDNA-ITS. J Appl Biosci 119:11943-11953

Brancini PTG, Tonani L, Rangel NED, Roberts WD, Braga LUG (2018) Species of the Metarhizium anisopliae complex with diverse ecological niches display different susceptibilities to antifungal agents. Fungal Biol:1-7

Chi M, Park S, Lee Y (2009) A quick and safe method for fungal DNA extraction. Plant Pathol J 25:108-111

Clifton HE, Jaronski TS, Hodgson WE, Gassmann JA (2015) Abundance of soilborne entomopathogenic fungi in organic and conventional fields in the Midwestern USA with an emphasis on the effect of herbicides and fungicides on fungal persistence. PLOS ONE 10:1-14

Conceschi RM, Moral AR, D'Alessandro PC, Demetri BGC, Junior DI (2016) Transmission potential of the entomopathogenic fungi Isaria fumosorosea and Beauveria bassiana from sporulated cadavers of Diaphorina citri and Toxoptera citricida to uninfected D. citri adults. Biol Control:1-11

Desneux N, Wajnberg E, Wyckhuys GAK, Burgio G, Arpaia S, Narváez-Vasquez AC, González-Cabrera J, Ruescas CD, Tabone E, Frandon J, Pizzol J, Poncet C, Cabello T, Urbaneja A (2010) Biological invasion of European tomato crops by Tuta absoluta: ecology, geographic expansion and prospects for biological control. J Pest Sci 83:197-215

Du C, Yang B, Wu J, Ali S (2019) Identification and virulence characterization of two akanthomyces attenuatus isolates against Megalurothrips usitatus (Thysanoptera: Thripidae). Insects 10:168-181

Fang WG, Lu HL, King GF, St. Leger RJ (2014) Construction of a hypervirulent and specific mycoinsecticide for locust control. Sci Rep 4:1-13

FAO (2017) Integrated pest management of major pests and diseases in Eastern Europe and the Caucasus, pp 1-110

Fernandes KK, Keyser AC, Chong PJ, Rangel NED, Miller MP, Roberts WD (2010) Characterization of Metarhizium species and varieties based on molecular analysis, heat tolerance and cold activity. J Appl Microbiol 108:115-128

Habtegebriel B, Getu E, Dawd M, Seyoum E, Atnafu G, Khamis F, Hilbur Y, Ekesi S, Larsson CM (2016) Molecular characterization and evaluation of indigenous entomopathogenic fungal isolates against Sorghum Chafer, Pachnoda interrupta (Olivier) inEthiopia. J Entomol Nematol 8:34-45

Lovett B, Bilgo E, Diabate A, St. Leger R (2019) A review of progress toward field application of transgenic mosquitocidal entomopathogenic fungi. Pest Manag Sci 75:2316-2324 
Mar TT, Lumyong S, Suwannarach N (2012) Isolation of entomopathogenic fungi from Northern Thailand and their production in cereal grains. World J Microbiol Biotechnol 28:3281-3291

Mayerhofer J, Lutz A, Dennert F, Rehner AS, Kepler MR, Widmer F, Enkerli J (2019) A species specific multiplexed PCR amplicon assay for distinguishing between Metarhizium anisopliae, M. brunneum, M. pingshaense and M. robertsii. J Invertebr Pathol 161:23-28

Meng X, Hu J, Ouyang G (2017) The isolation and identification of pathogenic fungi from Tessaratoma papillosa Drury (Hemiptera: Tessaratomidae). PeerJ 5:1-14

Meyling VN (2007) Methods for isolation of entomopathogenic fungi from the soil environment, Frederiksberg C, pp 1-19

Moonjely S, Bidochka JM (2019) Generalist and specialist Metarhizium insect pathogens retain ancestral ability to colonize plant roots. Fungal Ecol 41: 209-217

Ndereyimana A, Nyalala S, Murerwa P, Gaidashova S (2019) Pathogenicity of some commercial formulations of entomopathogenic fungion the tomato leaf miner, Tuta absoluta(Meyrick) (Lepidoptera: Gelechiidae). Egypt J Biol Pest Control 29:1-5

Nishi O, liyama K, Yasunaga-Aoki C, Shimizu S (2018) Abundance of the soil entomopathogenic fungus Metarhizium anisopliae sensu alto in agricultural field and forest soils in Japan. CREAM 8:468-473

Nishi O, Sato H (2019) Isolation of Metarhizium spp. from rhizosphere soils of wild plants reflects fungal diversity in soil but not plant specificity. Mycology 10:22-31

Niu X, Xie W, Zhang J, Hu Q (2019) Biodiversity of entomopathogenic fungi in the soils of South China. Microorganisms 7:1-14

Onsongo KS, Gichimu MB, Akutse SK, Dubois T, Mohamed AS (2019) Performance of three isolates of Metarhizium Anisopliae and their virulence against Zeugodacus Cucurbitae under different temperature regimes, with global extrapolation of their efficiency. Insects 10:270-283

Pires ML, Marques JE, De Oliveira VJ, Alves BS (2010) Seleção de Isolados de Fungos Entomopatogênicos para o Controle de Tuta absoluta (Meyrick) (Lepidoptera: Gelechiidae) e sua Compatibilidade com Alguns Inseticidas Usados na Cultura do Tomateiro. Neotrop Entomol 39:977-984

Posada JF, Vega EF (2005) A new method to evaluate the biocontrol potential of single spore isolates of fungal entomopathogens. J In Sci 5:1-10

Roditakis E, Grispou M, Nauen R, Vasakis E, Stavrakaki M, Gravouil M, Bassi A (2015) First report of Tuta absoluta resistance to diamide insecticides. J Pest Sci 88:9-16

Rwomushana I, Beale T, Chipabika G, Day R, Gonzalez-Moreno P, LamontagneGodwin J, Makale F, Pratt C, Tambo J (2019) Evidence Note: Tomato leafminer (Tuta absoluta): impacts and coping strategies for Africa. CABI Working Paper, pp 12-56

Sabbour MM, Singer SM (2014) Evaluations of two Metarhizium varieties against Tuta absoluta (Meyrick) (Lepidoptera: Gelechiidae) in Egypt. IJSR 3:1983-1987

Sain KS, Monga D, Kumar R, Nagrale TD, Hiremani SN, Kranthi S (2019) Compatibility of entomopathogenic fungi with insecticides and their efficacy for IPM of Bemisia tabaci in cotton. J Pestic Sci 44:97-105

Saleh MME, Abdel-Raheem AM, Ebadah MI, Elbehery HH (2016) Natural abundance of entomopathogenic fungi in fruit orchards and their virulence against Galleria mellonella larvae. Egypt J Biol Pest Control 26:203-207

San Aw MK, Hue MS (2017) Mode of infection of Metarhizium spp. fungus and their potential as biological control agents. Review. J Fungi 3:30-50

Sánchez-Peña RS, Lara SJ, Medina FR (2011) Occurrence of entomopathogenic fungi from agricultural and natural ecosystems in Saltillo, México, and their virulence towardsthrips and whiteflies. J Insect Sci 11:1-10

Santana AP, Kumar L, Da Silva SR, Picanço CM (2019) Global geographic distribution of Tuta absoluta as affected by climate change. J Pest Sci 92: 1373-1385

Shiberu T, Getu E (2018) Determination of the economic threshold level of tomato leaf miner, Tuta absoluta Meyrick (Lepidoptera: Gelechiidae) on tomato plant under glasshouse conditions. J Horticul For 10(2):9-16

Stranne S (2014)Species composition and abundance of entomopathogenic Metarhizium fungi in soils of a forest, pasture and agricultural field in Sweden. Uppsala BioCenter, Sweden, pp1-41.

Tadele S, Emana G (2017) Entomopathogenic effect of Beauveria bassiana (Bals.) and Metarrhizium anisopliae (Metschn.) on Tuta absoluta (Meyrick) (Lepidoptera: Gelechiidae) larvae under laboratory and glasshouse conditions in Ethiopia. J Plant Pathol Microbiol 8:411-414
Tangthirasunun N, Poeaim S, Soytong K, Sommartya P, Popoonsak S (2010) Variation in morphology and ribosomal DNA among isolates of Metarhizium anisopliae from Thailand. J Agri Technol 6:317-329

Tefera T, Pringle LK (2004) Evaluation of Beauveria bassiana and Metarhizium anisopliae for Controlling Chilo partellus (Lepidoptera: Crambidae) in Maize. Biocont Sci Technol 14:849-853

Vega EF, Meyling VN, Luangsa-ard JJ, Blackwell M (2012) Fungal entomopathogens. In: Insect Pathology, 2nd edn. Academic Press imprint of Elsevier, pp 171-220

Wang JB, St. Leger RJ, Wang C (2016) Advances in genomics of entomopathogenic fungi. In: Lovett B, St. Leger RJ (eds) Advances in Genetics. Academic Press Inc, pp 67-105

White TJ, Bruns T, Lee S, Taylor JW (1990) Amplification and direct sequencing of fungal ribosomal RNA genes for phylogenetics. In: Innis MA, Gelfand DH, Sninsky JJ, White TJ (eds) PCR Protocols: a guide to methods and applications. Academic Press Inc, New York, pp 315-322

\section{Publisher's Note}

Springer Nature remains neutral with regard to jurisdictional claims in published maps and institutional affiliations.

\section{Submit your manuscript to a SpringerOpen ${ }^{0}$ journal and benefit from:}

- Convenient online submission

- Rigorous peer review

- Open access: articles freely available online

- High visibility within the field

- Retaining the copyright to your article

Submit your next manuscript at $\boldsymbol{\sim}$ springeropen.com 